\title{
Neural Crest Stem Cells from Adult Bone Marrow: A New Source for Cell Replacement Therapy?
}

\author{
Aneta Glejzer ${ }^{1}$, Virginie Neirinckx ${ }^{1}$, \\ Bernard Rogister $1,2,3$ and Sabine Wislet-Gendebien ${ }^{1}$ \\ ${ }^{1}$ GIGA-Neurosciences, University of Liège, \\ ${ }^{2}$ GIGA-Development, Stem cells and Regeneative Medicine, University of Liège, \\ ${ }^{3}$ Neurology Department, $\mathrm{CHU}$, \\ Belgium
}

\section{Introduction}

Neurodegenerative disease is a generic term used for a wide range of acute and chronic conditions whose etiology is unknown such as Parkinson's disease, Huntington's disease, amyotrophic lateral sclerosis (ALS), Alzheimer's disease, but also now for other neurological diseases whose etiology is better known but which are also concerned by a chronic lost of neurons and glial cells such as multiple sclerosis (MS), stroke, and spinal cord injury. Although the adult brain contains small numbers of stem cells in restricted areas, the central nervous system exhibits limited capacity of regenerating lost tissue. Therefore, cell replacement therapies of lesioned brain have provided the basis for the development of potentially powerful new therapeutic strategies for a broad spectrum of human neurological diseases. However, the paucity of suitable cell types for cell replacement therapy in patients suffering from neurological disorders has hampered the development of this promising therapeutic approach.

Stem cells are classically defined as cells that have the ability to renew themselves continuously and possess pluripotent or multipotent ability to differentiate into many cell types. Besides the germ stem cells devoted to give rise to ovocytes or spermatozoïdes, those cells can be classified in three subgroups: embryonic stem cells (ES), induced pluripotent stem cells (iPS) and somatic stem cells (Figure 1). ES cells are derived from the inner mass of blastocyst and are considered as pluripotent stem cells as these cells can give rise to various mature cells from the three germ layers. iPS cells are also pluripotent stem cells, however, those cells derived from adult somatic cells such as skin fibroblasts are genetically modified by introduction of four embryogenesis-related genes (Takahashi et al., 2007; Park et al., 2008). Finally, tissue-specific stem cells known as somatic or adult stem cells are more restricted stem cells (multipotent stem cells) and are isolated from various fetal or adult tissues (i.e. hematopoietic stem cells, bone marrow mesenchymal stem cells, adipose tissuederived stem cells, amniotic fluid stem cells, neural stem cells, etc.; Reviewed by Kim and de Vellis, 2009). 


\section{PLURIPOTENT STEM CELLS}

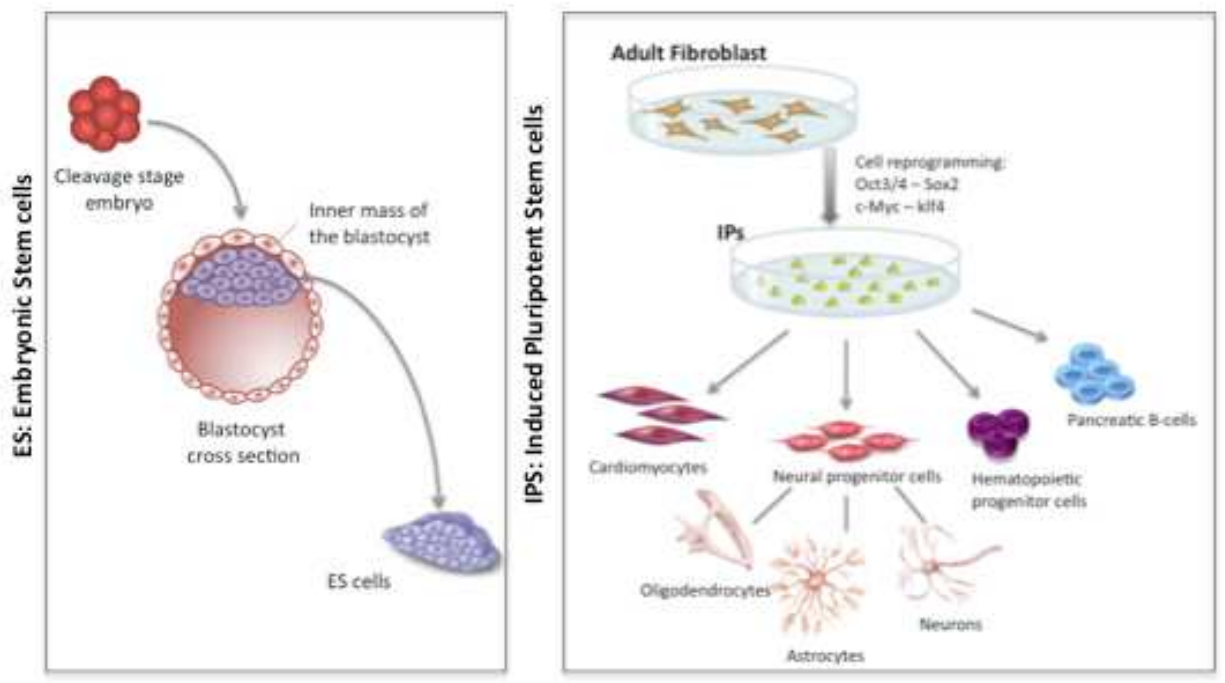

MULTIPOTENT STEM CELLS

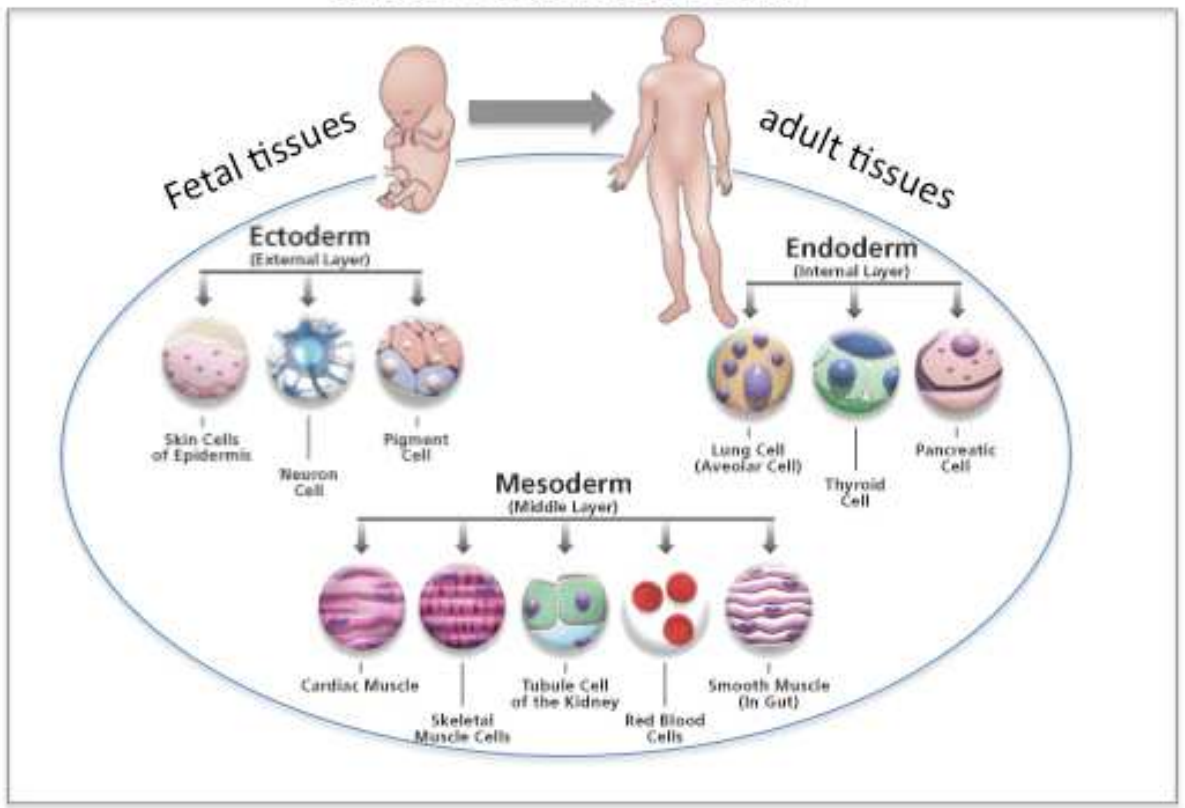

Fig. 1. Stem cell type and origin. Besides germ stem cells, three group of stem cells can be defined according to their differentiating abilities: A. pluripotent embryonic stem cells (ES), B. induced pluripotent stem cells (iPS) and C. multipotent fetal or adult somatic stem cells (Figure adapted from Sigma-Aldrich). 
In recent years, neurons and glial cells have been successfully generated from stem cells such as embryonic stem cells (Patani et al., 2010), iPS (Swistowski et al., 2010), mesenchymal stem cells (MSC) (Wislet-Gendebien et al., 2005), and adult neural stem cells (reviewed by Ming et Song, 2011), and extensive efforts by investigators to develop stem cell-based brain transplantation therapies have been carried out. Over the last decade, convincing evidence has emerged of the capability of various stem cell populations to induce regeneration in animal models of Parkinson's disease (PD), Huntington's disease, Alzheimer's disease (AD), multiple sclerosis or cerebral ischemia (Reviewed by Gögel et al., 2011). Some of the studies have already been carried out to clinical trials. In example, in the case of Parkinson's disease, transplantation of fetal ventral mesencephalon tissue directly into the brains of PD patients has been done in a few centers with varying results (Kordower et al., 2008; Li et al., 2008 ; Mendez et al., 2008) and it appeared that using fetal ventral mesencephalon tissue raised numerous problems from ethical issues to heterogeneity and relative scarcity of tissue (reviewed by Wakeman et al., 2011) suggesting that other stem cells (like adult somatic stem cells) may be more suitable for such a therapy. Likewise, ES cells have also been grafted in patients with injured spinal cord, as USA Federal Regulators have cleared the way for the first human trials of human ES-cell research, authorizing researchers to test whether those cells are safe or not (Schwarz et al., 2010). It is still to early to know the effect of ES cells on patient recovery; however, several concerns have been previously raised on animal models as ES cells induced teratocarcimas and some exploratory clinical trials are confirming the animal studies (reviewed by Solter, 2006).

In this chapter, we will review our results concerning identification and characterization of neural crest stem cells (NCSC) in adult bone marrow as a potential source for cellular therapy in neurological disorders. We will also discuss what are the main questions that remain pending concerning the use of those cells in cellular therapy protocols for neurological disorders.

\section{Somatic stem cells isolated from adult bone marrow}

The post-natal bone marrow has traditionally been seen as an organ composed of two main systems rooted in distinct lineages - the hematopoietic tissue and the associated supporting stroma. The evidence pointing to a putative stem cell upstream of the diverse lineages and cell phenotypes comprising the bone marrow stromal system has made marrow the only known organ in which two separate and distinct stem cells and dependent tissue systems not only coexist but functionally cooperate, defining hematopoietic stem cells (HSC) and mesenchymal stem cells (MSC) (reviewed by Bianco et al., 2001).

MSC were first isolated from the bone marrow (BM-MSC) stem cell niche. More recently, extensive research has revealed that cells with morphological and functional characteristics similar to BM-MSC can be identified in a large number of organs or tissues including adipose tissue and peripheral blood. Despite having different origins, these MSC populations maintain cell biological properties typically associated with stem cells. These include continuous cell cycle progression for self-renewal and the potential to differentiate into highly specialized cell types of the mesodermal phenotype including chondroblast, osteoblast, and adipocyte lineages. Interestingly, BM-MSC have also been reported to be inducible via the ectodermal or endodermal germline, demonstrating the expression of neuron-like factors insulin production or hepatic lineage-associated genes respectively. In addition to these general stem cell properties, the International Society for Cellular Therapy proposed a more specific panel of markers for the characterization of 
MSC. Due to the failure to identify a certain unique MSC cell-surface molecule, a set of minimal criteria for MSC was recommended, which includes the capability of adherence to plastic surfaces and the expression of the cell surface markers CD44, CD73, CD90, and CD105 with a concomitant absence of CD14, CD19, CD34, CD45, and HLA-DR expression (Reviewed by Hilfiker et al., 2011).

Originally analyzed because of their critical role in the formation of the hematopoietic microenvironment (HME), bone marrow stromal cells became interesting because of their surprising ability to differentiate into mature neural cell types. More recently, a third stem cell group has been identified as originating from the neural crest, which could explain the capacity of stromal stem cells to differentiate into functional neurons.

\subsection{Neural phenotypic plasticity of adult bone marrow stromal cells}

Several years ago, we demonstrated that a fraction of bone marrow stromal cells were able to differentiate into functional neurons. Those specific cells were characterized as nestinpositive mesenchymal stem cells (Wislet-Gendebien, 2003-2005). Electrophysiological analyses using the whole-cell patch-clamp technique revealed that adult rat bone marrow stromal cells (Wislet-Gendebien et al., 2005a and 2005b) were able to differentiate into excitable neuron-like cells when they were co-cultivated with mouse cerebellar granule neurons. First, we demonstrated that those cells express several neuronal markers (NeuN and Beta-III-tubulin ; Figure 2), an axonal marker (neurofilament protein recognized by the

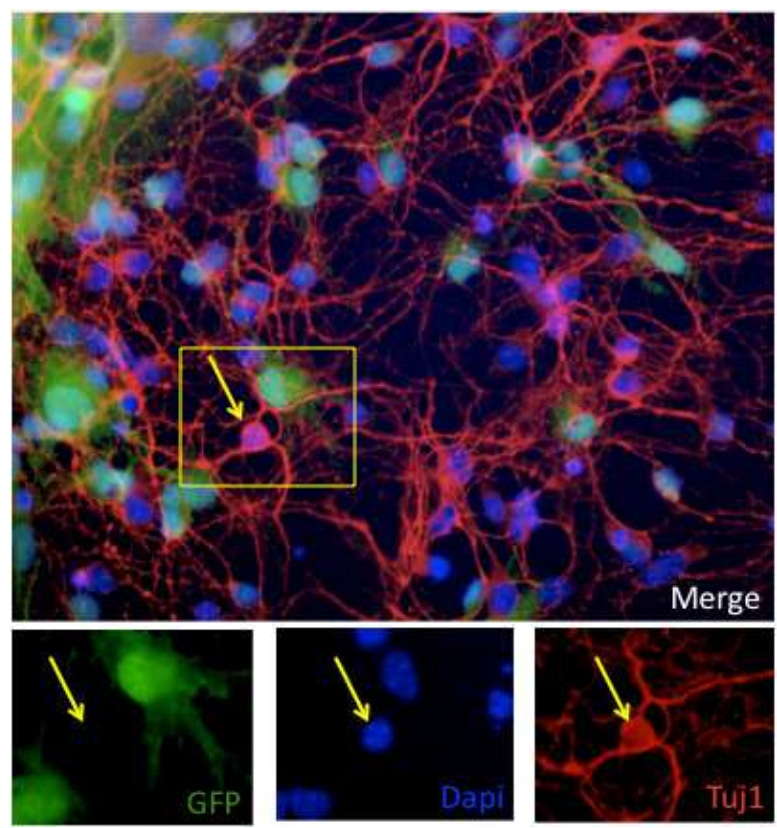

Fig. 2. Neuronal marker expressed by bone marrow stromal cells. Bone marrow stromal cells were co-cultivated for 5 days with GFP-positive cerebellar granule neurons (green). Immunofluorescence labeling showed that beta-III tubulin recognize by Tuj 1 antibodies (red) was expressed by about $20 \%$ of bone marrow stromal cells (GFP-negative or non-green cells) (Wislet-Gendebien et al., 2005). 
monoclonal antibody, SMI31) and a dendritic marker (MAP2ab). Electrophysiological recordings of these nestin-positive bone marrow-derived neuron-like cells (BMDN) were performed and three maturation stages were observed (Table 1). At 4-6 days of co-culture, BMDN showed some neurotransmitter responsiveness (GABA, glycine, serotonin and glutamate) and voltage-gated $\mathrm{K}^{+}$currents inhibited by TEA (tetraethylammonium). However, those cells did not express functional sodium voltage-gated channels and have a low membrane potential (Vrest) $\left(-37.6^{\circ} \pm 3 \mathrm{mV}, n=61\right)$. During the second week of coculture, BMDN started to display $\mathrm{Na}^{+}$currents reversely inhibitsed by TTX (tetrodotoxin) and became able to fire single spike of action potential. In those older co-cultures, the Vrest reaches a more negative value, which was closer to the value usually measured in neurons (7-9 days, $-50.3 \pm 2 \mathrm{mV}, n=76$ and $10-15$ days, $-56.7 \pm 2.3 \mathrm{mV}, n=97$ ).

As only nestin-positive bone marrow stromal cells were able to differentiate into functional neurons, we performed several proteomic and transcriptomic comparisons that pointed out several characteristics like ErbB3 and Sox10 over-expression in nestin-positive MSC, suggesting that these cells could actually be neural-crest derived cells (reviewed by WisletGendebien et al., 2008). Few months later, Nogoshi et al. (2008) confirmed the presence of neural crest derived cells in adult bone marrow.

\begin{tabular}{lccc|}
\hline Maturation of BMDN & $\begin{array}{l}\mathbf{5} \text { Days in } \\
\text { vitro }\end{array}$ & $\begin{array}{l}\mathbf{8} \text { Days in } \\
\text { vitro }\end{array}$ & $\mathbf{1 2}$ Days in vitro \\
\hline Neurotransmitter sensitivities & $\begin{array}{c}\text { GABA, Glycin, } \\
\text { Glutamate }\end{array}$ & $\begin{array}{c}\text { GABA, Glycin, } \\
\text { Glutamate }\end{array}$ & $\begin{array}{c}\text { GABA, Glycin, } \\
\text { Glutamate }\end{array}$ \\
$\begin{array}{l}\text { Potassic voltage-gated } \\
\text { channels }\end{array}$ & +++ & +++ & ++ \\
\hline Sodic voltage-gated channels & - & +++ & +++ \\
\hline Action potentials & - & ++ & +++ \\
\hline Trains of action potentials & - & - & - \\
\hline Synaptic activities & - & - & - \\
\hline Membrane potential (mV) & $-37 \pm 3$ & $-50,3 \pm 2$ & $-57,7 \pm 2,3$ \\
\hline
\end{tabular}

Table 1. Maturation steps of bone marrow derived neuron-like cells

\subsection{Characterization of neural crest stem cells from adult bone marrow 2.2.1 Neural crest stem cell origin}

In early vertebrate development, the neural crest is specified in the embryonic ectoderm at the boundary of the neural plate and the ectoderm. Once specified, the neural crest cells undergo a process of epithelium to mesenchyme transition (EMT) that will confer them the ability to migrate. The EMT involves different molecular and cellular machineries and implies deep changes in cell morphology and in the type of cell surface adhesion and recognition molecules. When the EMT is complete, they delaminate from the neural 
folds/neural tube and migrate along characteristic pathways to differentiate into a wide variety of derivates (Figure 3; reviewed by Kalcheim, 2000).

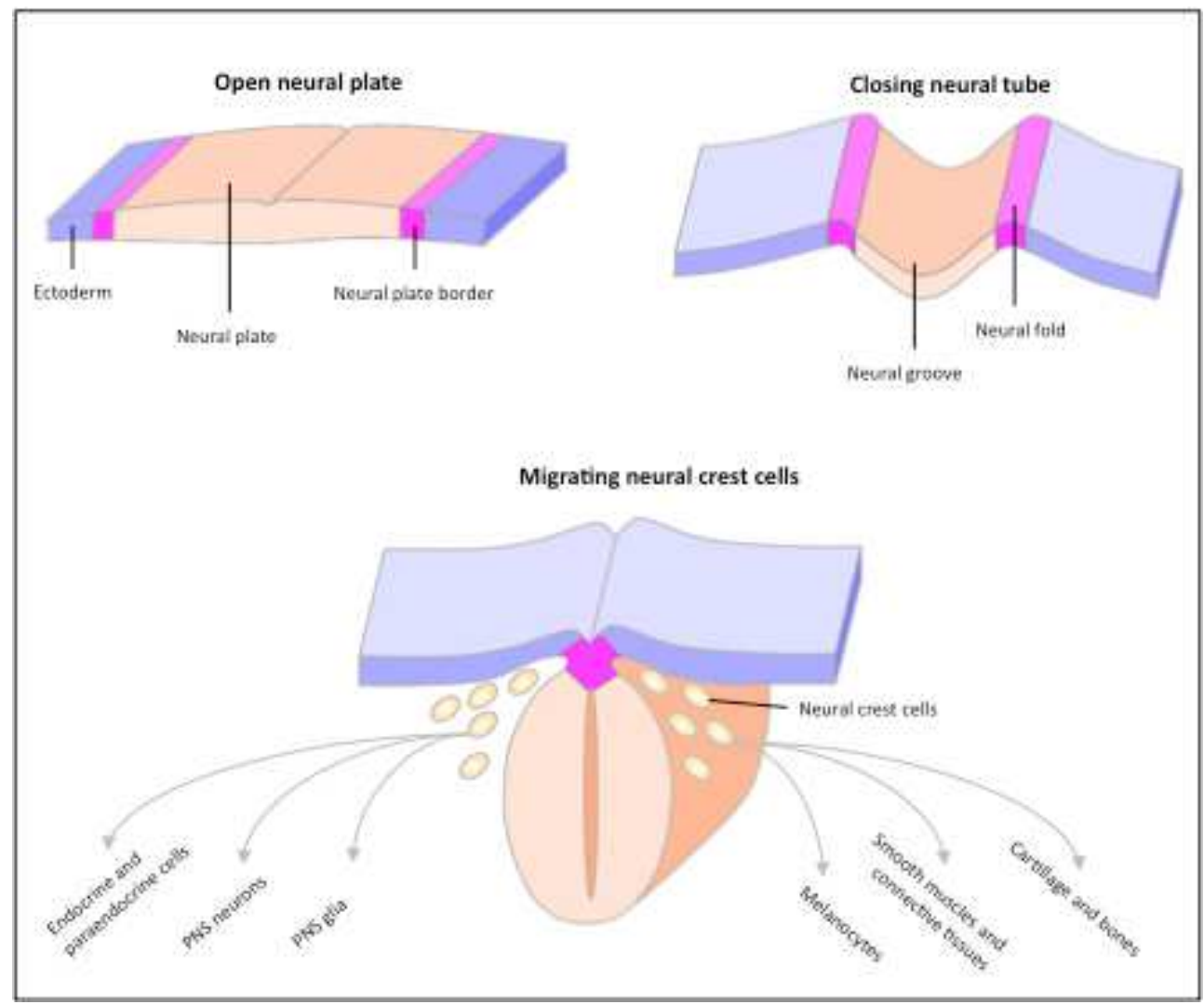

Fig. 3. Neurulation and neural crest migration. As neurulation proceeds, the neural plate rolls up and the neural plate border becomes the neural folds. Near the time of neural tube closure (depending on the species), the neural crest cells go through an epithelial to mesenchymal transition (EMT) and delaminate from the neural folds or dorsal neural tube and migrate along defined pathways.

In 2000, Jiang et al. developed a two-component genetic system based on Cre/lox recombination to label indelibly the entire mouse neural crest population at the time of its formation, and to detect it at any time thereafter. Briefly, the fate of neural crest cells was 
mapped in vivo by mating ROSA26 Cre reporter (R26R) mice, which express $\beta$ galactosidase upon Cre-mediated recombination, with mice expressing Cre recombinase under the control of the Wnt1 promoter. In Wnt1-Cre/R26R double transgenic mice, virtually all neural crest stem cells express $\beta$-galactosidase. Using this transgenic model, Sieber-Blum and Grim (2004) demonstrated the presence of pluripotent neural crest stem cells in adult follicle hairs, Wong et al. (2006) demonstrated the presence of neural crest cells in the mouse adult skin and Nagoshi et al. (2008) confirmed the presence of NCSC in adult bone marrow (Table 2).

\begin{tabular}{|c|c|c|c|c|}
\hline Place & Marker & Animal & Genotype & Reference \\
\hline Gut & P7SNTR & Rat & Wild type & Kruger et al., 2002 \\
\hline DRG & & Rat & Wild type & Li et al., 2007 \\
\hline $\begin{array}{l}\text { DRG, Whisker } \\
\text { pad, bone marrow }\end{array}$ & EGFP & Mouse & $\begin{array}{l}\text { P0 } \\
\text { Wht1-CRE/CAG-EGFP }\end{array}$ & Nagoshi et al., 2008 \\
\hline Skin & & Mouse & Wild type & Toma et al., 2005 \\
\hline Skin & LacZ & Mouse & Wht1-CRE/ROSA-LacZ & Sieber-Blum et al., 2004 \\
\hline Skin & EYFP & Mouse & Dct-Cre/ROSA-EYFP & Wong et al., 2006 \\
\hline Cornea & EGFP & Mouse & $\begin{array}{l}\text { P0 } \\
\text { Wht1-CRE/CAG-EGFP }\end{array}$ & Yoshida et al., 2006 \\
\hline Carotide body & EGFP & Mouse & GFAP promotor-EGFP & Pardal et al., 2007 \\
\hline
\end{tabular}

Table 2. Presence of neural crest derived cells in adult tissues.

\subsubsection{Self-renewal ability and multipotency of adult bone marrow NCSC}

To consider NCSC from adult bone marrow as a potential source for cellular therapy protocol, a better characterization of those cells was mandatory. In our study, we first address the self-renewal ability, as first characteristic of stemness. Indeed, we demonstrated that NCSC were able to grow as spheres, which is one of the main hallmarks of immature neural cells and proliferate from a single cell culture (clonal culture). We then addressed the multipotency and verify if those NCSC clones were able to differentiate into multiple mature cell types. Indeed, we observed that NCSC were able to differentiate into adipocytes, melanocytes, smooth muscles, osteocytes, neurons and astrocytes (Figure 4, Glejzer et al., 2011).

\subsubsection{Maintenance and proliferation of adult bone marrow NCSC}

Before using NCSC from adult bone marrow, we have to face some limiting factors like the fact that NCSC are a minority population (less than 1\%) in adult bone marrow. As Wnt1 and BMP2 factors were described to help for maintenance and proliferation of NCSC isolated from embryo (Sommer, 2006), we tested those two factors, on adult NCSC isolated from adult bone marrow. Interestingly, we demonstrated that Wnt1 and BMP2 were able to increase the number of NCSC present in bone marrow stromal cell culture, up to four times within 2 passages (Glejzer et al., 2011) reaching $20 \%$ of NCSC. 

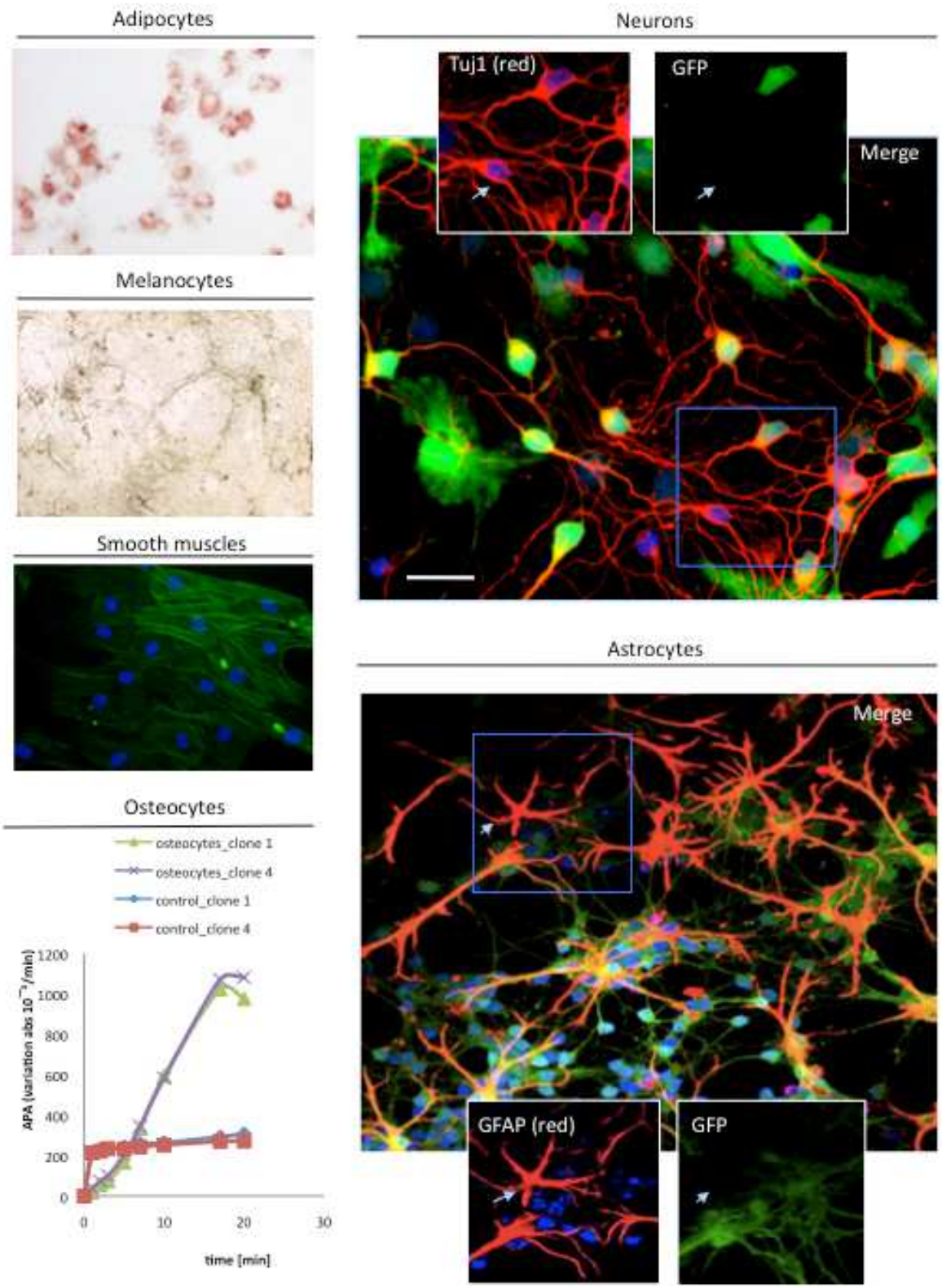

Fig. 4. Multipotency of adult bone marrow NCSC. NCSC clones were subjected to differentiating protocols and were shown to be able to differentiate into adipocytes (Oil Red O labeling), melanocytes (L-DOPA labeling), smooth muscles (SMA-labeling) and Osteocytes (alkaline phosphatase activity). Moreover, when co-cultured with cerebellar granule neurons, we were able to differentiate NCSC clones into neurons (betaIII-tubulin labeling by Tuj1 monoclonal antibody) or astrocytes (GFAP labeling). 


\section{In vivo characterization of neural crest stem cells and/or bone marrow stromal cells in neurological disorder mice models}

\subsection{Spinal stroke}

Among others, the spinal cord is the collection of fibers that runs from or to the brain through the spine, carrying signals from or to the brain to or from the rest of the body. Those signals control a person's muscles and enable the person to feel various sensations. The main consequence of injuries to the spinal cord is the interference with those signals. Those injuries are characterized as "complete" or "incomplete": if the injured person loses all sensation and all ability to control the muscles below the point of the injury, the injury is said "complete"; in the case of an "incomplete" injury, the victim retains some ability to feel sensations or control movement below the injured area.

Main goals in spinal cord repair include reconnecting brain and lower spinal cord, building new circuits, re-myelination of demyelinated axons, providing trophic support, and bridging the gap of the lesion (Reviewed by Enzmann et al., 2006). Overcoming myelinassociated and/or glial-scar-associated growth inhibition are experimental approaches that have been most successfully studied in in vivo experiments. Further issues concern gray matter reconstitution and protecting neurons and glia from secondary death (Reviewed by Enzmann et al., 2006).

In this purpose, neural crest stem cells isolated from the bulge of hair follicle have been grafted in rat model of spinal cord lesion (reviewed by Sieber-Blum 2010). Those cells survived, integrated and intermingled with host neurites in the lesioned spinal cord. NCSC were non-migratory and did not proliferate or form tumors. Significant subsets of grafted cells expressed the neuron-specific beta-III tubulin, the GABAergic marker glutamate decarboxylase 67 (GAD67), the oligodendrocyte markers RIP or myelin basic protein (MBP) (Sieber-Blum et al., 2006). More interestingly, functional improvement was shown by two independent approaches, spinal somatosensory evoked potentials (SpSEP) and the SemmesWeinstein touch test (Hu et al., 2010). The strength of NSCS was fully characterized as they can exert a combination of pertinent functions in the contused spinal cord, including cell replacement, neuroprotection, angiogenesis and modulation of scar formation. However, those results have never been confirmed with human NCSC, which should be the next promising step.

Similar studies were previously performed with bone marrow stromal cells. Indeed, several researches reported the anti-proliferative, anti-inflammatory and anti-apoptotic features of bone marrow stromal cells (reviewed by Uccelli et al., 2011). Indeed, Zeng et al. (2011) demonstrated that BMSC seeded in a three dimensions gelatin sponge scaffold and transplanted in a transected rat spinal cord resulted in attenuation of inflammation, promotion of angiogenesis and reduction of cavity formation. Those BMSC were isolated from 10 weeks old rats and passaged 3 to 6 times. Likewise, $\mathrm{Xu}$ et al. (2010) demonstrated that a co-culture of Schwann cell with BMSC had greater effects on injured spinal cord recovery than untreated BMSC. Indeed, analyses of chemokine and cytokine expression revealed that BMSC/Schwann cell co-cultures produced far less MCP-1 and IL-6 than BMSC or Schwann cells cultured alone. Transplanted BMSC may thus improve recovery in spinal cord injured mice through immunosuppressive effects that can be enhanced by a Schwann cell co-culturing step. These results indicate that the temporary presence of BMSC in the 
injured cord is sufficient to alter the cascade of pathological events that normally occurs after spinal cord injury and therefore, generating a microenvironment which favours an improved recovery. In this study, BMSC were isolated from adult mice and used after 4 passages.

\subsection{Multiple sclerosis}

Multiple sclerosis (MS) is a common neurological disease and a major cause of disability, particularly affecting young adults. It is characterized by patches of damage occurring throughout the brain and spinal cord with loss of myelin sheaths accompanied by loss of cells that make myelin (oligodendrocytes) (reviewed by Scolding, 2011). In addition, we now know that there is damage to neurons and their axons too, and that this occurs both within these discrete patches and in tissue between them. The cause of MS remains unknown, but an autoimmune reaction against oligodendrocytes and myelin is generally assumed to play a major role and early acute MS lesions almost invariably show prominent inflammation. Efforts to develop cell therapy of nervous system lesion in MS have long been directed towards directly implanting cells capable of replacing lost oligodendrocytes and regenerating myelin sheaths.

To our knowledge, no experiment has been performed to characterize the effect of neural crest stem cells on the improvement of Multiple Sclerosis disease; however, several data can be collected concerning the positive effect of Schwann cells (derived from NCSC) and of bone marrow stromal cells.

As previously described in injured spinal cord, bone marrow stromal cells have been characterized on their anti-proliferative, anti-inflammatory and anti-apoptotic features. These properties have been exploited in the effective treatment of experimental autoimmune encephalomyelitis (EAE), an animal model of multiple sclerosis where the inhibition of the autoimmune response resulted in a significant neuroprotection (reviewed by Uccelli et al., 2011). Based on recent experimental data, a number of clinical trials have been designed for the intravenous (IV) and/or intrathecal (ITH) administration of BMSCs in MS patients (Grigoriadis et al., 2011).

\subsection{Parkinson disease}

Parkinson's disease (PD) is a chronic, progressive neurodegenerative disorder characterized by a continuous and selective loss of dopaminergic neurons in the substantia nigra pars compacta with a subsequent reduction of dopamine release mainly in the striatum. This ongoing loss of nigral dopaminergic neurons leads to clinical diagnosis mainly due to occurrence of motor symptoms such as rigidity, tremor and bradykinesia, which result from a reduction of about $70 \%$ of striatal dopamine (reviewed by Meyer et al., 2010).

Levy et al. (2008) analyzed the effect of differentiated human BMSC onto dopaminergic precursor on hemi-Parkinsonian rats, after transplantation into striatum. This graft resulted in improvement of rat behavioral deficits quantified by apomorphine-induced rotational behavior. The transplanted induced-neuronal cells proved to be of superior benefit compared with the transplantation of naive BMSC. Immunohistochemical analysis of grafted brains revealed that abundant induced cells survived the grafting procedure and some of these cells displayed dopaminergic traits. 
Similarly, Zhang et al. (2008) isolated and characterized MSCs from Parkinson's disease (PD) patients and compared them with MSCs derived from normal adult bone marrow. These authors show that PD-derived MSCs are similar to normal MSCs in phenotype, morphology, and differentiation capacity. Moreover, PD-derived MSCs are able of differentiating into neurons in a specific medium with up to $30 \%$ having the characteristics of dopamine cells. At last, PD-derived MSCs could inhibit T-lymphocyte proliferation induced by mitogens. These findings indicate that MSCs derived from PD patients' bone marrow could be a promising cell type for cellular therapy and somatic gene therapy applications.

\subsection{Huntington disease}

Huntington disease (HD) is an autosomal dominant genetic disorder caused by the expansion of polyglutamine encoded by CAG repeats in Exon 1 of the IT15 gene encoding for Huntingtin (Htt). The polyglutamine repeat length determines the age of onset and the overall level of function, but not the severity of the disease (Vassos et al., 2007). Although the exact mechanism underlying HD disease progression remains uncertain, the hallmark of this disease is a gross atrophy of the striatum and cortex and a decrease of GABAergic neurons (DiFiglia et al., 1997).

One strategy for HD therapy is to enhance neurogenesis, which has been studied by the administration of Stem/progenitor cells, including BMSC. Several studies (reviewed by Snyder et al., 2010) showed that BMSC promote repair of the CNS by creating a more favorable environment for neuroprotection and regeneration through the secretion of various cytokines and chemokines. Moreover, Snyder et al. (2010) demonstrated that BMSC injected into the dentate gyrus of HD mice model increased neurogenesis and decreased atrophy of the striatum.

\subsection{Alzheimer disease}

Alzheimer's disease (AD) is the most common form of dementia, affecting more than 18 million people worldwide. With increased life expectancy, this number is expected to rise in the future. $\mathrm{AD}$ is characterized by progressive memory deficits, cognitive impairment, and personality changes associated with the degeneration of multiple neuronal types and pathologically by the presence of neuritic or amyloid plaques and neurofibrillary tangles (Reviewed by Selko, 2001). Amyloid $\beta$-peptide $(A \beta)$ appears to play a key pathogenic role in $\mathrm{AD}$, and studies have connected $\mathrm{A} \beta$ plaques with the formation of intercellular tau tangles, another neurotoxic feature of AD (Reviewed by Mattson, 2004). Currently, no treatment is available to cure or prevent the neuronal cell death that results in inevitable decline in $\mathrm{AD}$ patients.

The innate immune system is the vital first line of defense against a wide range of pathogens and tissue injuries, triggering inflammation through activation of microglia and macrophages. Many studies have shown that microglia are attracted to and surround senile plaques both in human $\mathrm{AD}$ samples and in rodent transgenic models that develop ADrelated disease (Simard et al., 2006). In this context, Lee and al. (2010) demonstrated that treated APP/PS1 mice (mouse model of AD) with BM-MSCs promoted microglial activation, rescued cognitive impairment, and reduced $A \beta$ and tau pathology in the mouse brain. 


\section{Conclusions}

The NCSC is one of the most intriguing cells in the field of regenerative medicine, because it is easily harvested from various accessible peripheral tissues, which could make autologous transplantation possible. Autologous transplantation would avoid immunological complications as well as the ethical concerns associated with the use of embryonic stem cells. Of the various NCSC, research on skin-derived NCSC is the most advanced mainly due to their easy isolation process. One of the critical questions for the application of NCSC to regenerative medicine is whether cells that are differentiated from NCSCs are functional. Some evidence supports this (reviewed by Nagoshi et al., 2009), however, lots of questions remained pending. By example, a very important question is the differentiation abilities of NCSC isolated from various tissues: are they similar or different?

On the other hand, even if bone marrow stromal cells did not show a strong ability to replace lost neurons in neurodegenerative disorders such as Parkinson or Huntington disease, their impact on inflammation modulation or stimulation of endogenous cells were quite remarkable. This impact is also illustrated by a high number of ongoing clinical trials with these cells (Reviewed by Sensebé et Bourin, 2011). However, the main challenges remain the standardization of cell culture and isolation, to meet the international rules. Indeed, more than ever, it has been demonstrated that bone marrow stromal cells are constituted of an heterogenous population containing multiple stem/progenitor cell types including mesenchymal stem cells and neural crest stem cells, among other. Most of the studies describing the effects of BMSC on inflammation modulation or stimulation of endogenous cells were performed on low passages $(<4)$, which mainly contain MSC and less than $10 \%$ of NCSC. So we could stipulate that most of these effects were probably due to MSC. However, in a perspective of cell therapy, a strong characterization of the role of each cell type in neuronal recovery seemed mandatory to establish strong and safe protocols.

\section{Acknowledgment}

Our work presented in this review was supported by grants from the Fonds National de la Recherche Scientifique (FNRS) of Belgium, by a grant of the Action de Recherche Concertée de la Communauté Française de Belgique, and by the Belgian League against Multiple Sclerosis associated with Leon Fredericq Foundation. AG is a Marie Curie Host Fellow for Early Stage Research Training, EURON 020589 within the 6th FP of the EU, Marie Curie Actions - Human Resources and Mobility.

\section{References}

Bianco P, Riminucci M, Gronthos S, Robey PG (Bone marrow stromal stem cells: nature, biology, and potential applications. Stem Cells 19:180-192.2001).

DiFiglia M, Sapp E, Chase KO, Davies SW, Bates GP, Vonsattel JP, Aronin N (Aggregation of huntingtin in neuronal intranuclear inclusions and dystrophic neurites in brain. Science 277:1990-1993.1997). 
Enzmann GU, Benton RL, Talbott JF, Cao Q, Whittemore SR (Functional considerations of stem cell transplantation therapy for spinal cord repair. J Neurotrauma 23:479495.2006).

Glejzer A, Laudet E, Leprince P, Hennuy B, Poulet C, Shakhova O, Sommer L, Rogister B, Wislet-Gendebien S (Wnt1 and BMP2: two factors recruiting multipotent neural crest progenitors isolated from adult bone marrow. Cell Mol Life Sci 68:21012114.2011).

Gogel S, Gubernator M, Minger SL (Progress and prospects: stem cells and neurological diseases. Gene Ther 18:1-6.2011).

Grigoriadis N, Lourbopoulos A, Lagoudaki R, Frischer JM, Polyzoidou E, Touloumi O, Simeonidou C, Deretzi G, Kountouras J, Spandou E, Kotta K, Karkavelas G, Tascos $\mathrm{N}$, Lassmann H (Variable behavior and complications of autologous bone marrow mesenchymal stem cells transplanted in experimental autoimmune encephalomyelitis. Exp Neurol 230:78-89.2011).

Hilfiker A, Kasper C, Hass R, Haverich A (Mesenchymal stem cells and progenitor cells in connective tissue engineering and regenerative medicine: is there a future for transplantation? Langenbecks Arch Surg 396:489-497.2011).

Hu SL, Luo HS, Li JT, Xia YZ, Li L, Zhang LJ, Meng H, Cui GY, Chen Z, Wu N, Lin JK, Zhu $\mathrm{G}$, Feng $\mathrm{H}$ (Functional recovery in acute traumatic spinal cord injury after transplantation of human umbilical cord mesenchymal stem cells. Crit Care Med 38:2181-2189.2010).

Jiang X, Rowitch DH, Soriano P, McMahon AP, Sucov HM (Fate of the mammalian cardiac neural crest. Development 127:1607-1616.2000).

Kalcheim C (Mechanisms of early neural crest development: from cell specification to migration. Int Rev Cytol 200:143-196.2000).

Kim SU, de Vellis J (Stem cell-based cell therapy in neurological diseases: a review. J Neurosci Res 87:2183-2200.2009).

Kordower JH, Chu Y, Hauser RA, Freeman TB, Olanow CW (Lewy body-like pathology in long-term embryonic nigral transplants in Parkinson's disease. Nat Med 14:504506.2008).

Kruger GM, Mosher JT, Bixby S, Joseph N, Iwashita T, Morrison SJ (Neural crest stem cells persist in the adult gut but undergo changes in self-renewal, neuronal subtype potential, and factor responsiveness. Neuron 35:657-669.2002).

Levy YS, Bahat-Stroomza M, Barzilay R, Burshtein A, Bulvik S, Barhum Y, Panet H, Melamed E, Offen D (Regenerative effect of neural-induced human mesenchymal stromal cells in rat models of Parkinson's disease. Cytotherapy 10:340-352.2008).

Li HY, Say EH, Zhou XF (Isolation and characterization of neural crest progenitors from adult dorsal root ganglia. Stem Cells 25:2053-2065.2007).

Li JY, Englund E, Holton JL, Soulet D, Hagell P, Lees AJ, Lashley T, Quinn NP, Rehncrona S, Bjorklund A, Widner H, Revesz T, Lindvall O, Brundin P (Lewy bodies in grafted neurons in subjects with Parkinson's disease suggest host-to-graft disease propagation. Nat Med 14:501-503.2008). 
Mattson MP (Pathways towards and away from Alzheimer's disease. Nature 430:631639.2004).

Mendez I, Vinuela A, Astradsson A, Mukhida K, Hallett P, Robertson H, Tierney T, Holness R, Dagher A, Trojanowski JQ, Isacson O (Dopamine neurons implanted into people with Parkinson's disease survive without pathology for 14 years. Nat Med 14:507509.2008).

Meyer M, Jensen P, Rasmussen JZ ([Stem cell therapy for neurodegenerative disorders]. Ugeskr Laeger 172:2604-2607.2010).

Ming GL, Song H (Adult neurogenesis in the Mammalian brain: significant answers and significant questions. Neuron 70:687-702.2011).

Nagoshi N, Shibata S, Kubota Y, Nakamura M, Nagai Y, Satoh E, Morikawa S, Okada Y, Mabuchi Y, Katoh H, Okada S, Fukuda K, Suda T, Matsuzaki Y, Toyama Y, Okano $\mathrm{H}$ (Ontogeny and multipotency of neural crest-derived stem cells in mouse bone marrow, dorsal root ganglia, and whisker pad. Cell Stem Cell 2:392-403.2008).

Nagoshi N, Shibata S, Nakamura M, Matsuzaki Y, Toyama Y, Okano H (Neural crestderived stem cells display a wide variety of characteristics. J Cell Biochem 107:10461052.2009).

Pardal R, Ortega-Saenz P, Duran R, Lopez-Barneo J (Glia-like stem cells sustain physiologic neurogenesis in the adult mammalian carotid body. Cell 131:364377.2007).

Park IH, Zhao R, West JA, Yabuuchi A, Huo H, Ince TA, Lerou PH, Lensch MW, Daley GQ (Reprogramming of human somatic cells to pluripotency with defined factors. Nature 451:141-146.2008).

Patani R, Hollins AJ, Wishart TM, Puddifoot CA, Alvarez S, de Lera AR, Wyllie DJ, Compston DA, Pedersen RA, Gillingwater TH, Hardingham GE, Allen ND, Chandran S (Retinoid-independent motor neurogenesis from human embryonic stem cells reveals a medial columnar ground state. Nat Commun 2:214.2011).

Schwarz SC, Schwarz J (Translation of stem cell therapy for neurological diseases. Transl Res 156:155-160.2010).

Scolding N (Adult stem cells and multiple sclerosis. Cell Prolif 44 Suppl 1:35-38.2011).

Sensebe L, Bourin P, Tarte K (Good manufacturing practices production of mesenchymal stem/stromal cells. Hum Gene Ther 22:19-26.2011).

Sieber-Blum M (Epidermal neural crest stem cells and their use in mouse models of spinal cord injury. Brain Res Bull 83:189-193.2010).

Sieber-Blum M, Grim M, Hu YF, Szeder V (Pluripotent neural crest stem cells in the adult hair follicle. Dev Dyn 231:258-269.2004).

Simard AR, Soulet D, Gowing G, Julien JP, Rivest S (Bone marrow-derived microglia play a critical role in restricting senile plaque formation in Alzheimer's disease. Neuron 49:489-502.2006).

Snyder BR, Chiu AM, Prockop DJ, Chan AW (Human multipotent stromal cells (MSCs) increase neurogenesis and decrease atrophy of the striatum in a transgenic mouse model for Huntington's disease. PLoS One 5:e9347.2010). 
Solter D (From teratocarcinomas to embryonic stem cells and beyond: a history of embryonic stem cell research. Nat Rev Genet 7:319-327.2006).

Sommer L (Growth factors regulating neural crest cell fate decisions. Adv Exp Med Biol 589:197-205.2006).

Swistowski A, Peng J, Liu Q, Mali P, Rao MS, Cheng L, Zeng X (Efficient generation of functional dopaminergic neurons from human induced pluripotent stem cells under defined conditions. Stem Cells 28:1893-1904.2010).

Takahashi K, Okita K, Nakagawa M, Yamanaka S (Induction of pluripotent stem cells from fibroblast cultures. Nat Protoc 2:3081-3089.2007).

Toma JG, McKenzie IA, Bagli D, Miller FD (Isolation and characterization of multipotent skin-derived precursors from human skin. Stem Cells 23:727737.2005).

Uccelli A, Benvenuto F, Laroni A, Giunti D (Neuroprotective features of mesenchymal stem cells. Best Pract Res Clin Haematol 24:59-64.2011).

Vassos E, Panas M, Kladi A, Vassilopoulos D (Effect of CAG repeat length on psychiatric disorders in Huntington's disease. J Psychiatr Res 42:544549.2008).

Wakeman DR, Dodiya HB, Kordower JH (Cell transplantation and gene therapy in Parkinson's disease. Mt Sinai J Med 78:126-158.2011).

Wautier F, Wislet-Gendebien S, Chanas G, Rogister B, Leprince P (Regulation of nestin expression by thrombin and cell density in cultures of bone mesenchymal stem cells and radial glial cells. BMC Neurosci 8:104.2007).

Wislet-Gendebien S, Hans G, Leprince P, Rigo JM, Moonen G, Rogister B (Plasticity of cultured mesenchymal stem cells: switch from nestin-positive to excitable neuronlike phenotype. Stem Cells 23:392-402.2005).

Wislet-Gendebien S, Leprince P, Moonen G, Rogister B (Regulation of neural markers nestin and GFAP expression by cultivated bone marrow stromal cells. J Cell Sci 116:32953302.2003).

Wislet-Gendebien S, Wautier F, Leprince P, Rogister B (Astrocytic and neuronal fate of mesenchymal stem cells expressing nestin. Brain Res Bull 68:95102.2005).

Wong CE, Paratore C, Dours-Zimmermann MT, Rochat A, Pietri T, Suter U, Zimmermann DR, Dufour S, Thiery JP, Meijer D, Beermann F, Barrandon Y, Sommer L (Neural crest-derived cells with stem cell features can be traced back to multiple lineages in the adult skin. J Cell Biol 175:1005-1015.2006).

Xu X, Geremia N, Bao F, Pniak A, Rossoni M, Brown A (Schwann cell co-culture improves the therapeutic effect of bone marrow stromal cells on recovery in spinal cordinjured mice. Cell Transplant.2010).

Yoshida S, Shimmura S, Nagoshi N, Fukuda K, Matsuzaki Y, Okano H, Tsubota K (Isolation of multipotent neural crest-derived stem cells from the adult mouse cornea. Stem Cells 24:2714-2722.2006).

Zeng X, Zeng YS, Ma YH, Lu LY, Du BL, Zhang W, Li Y, Chan WY (Bone Marrow Mesenchymal Stem Cells in a Three Dimensional Gelatin Sponge Scaffold Attenuate Inflammation, Promote Angiogenesis and 
Reduce Cavity Formation in Experimental Spinal Cord Injury. Cell Transplant.2011).

Zhang Z, Wang X, Wang S (Isolation and characterization of mesenchymal stem cells derived from bone marrow of patients with Parkinson's disease. In Vitro Cell Dev Biol Anim 44:169-177.2008). 


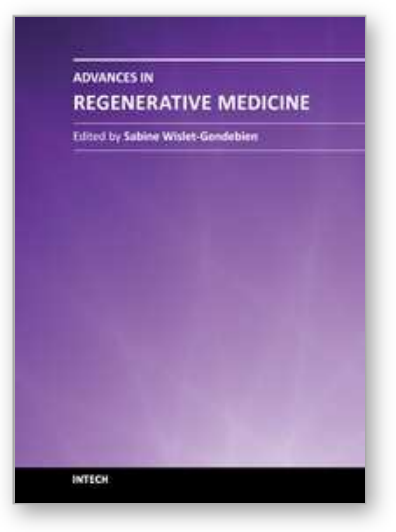

\author{
Advances in Regenerative Medicine \\ Edited by Dr Sabine Wislet-Gendebien
}

ISBN 978-953-307-732-1

Hard cover, 404 pages

Publisher InTech

Published online 21, November, 2011

Published in print edition November, 2011

Even if the origins of regenerative medicine can be found in Greek mythology, as attested by the story of Prometheus, the Greek god whose immortal liver was feasted on day after day by Zeus' eagle; many challenges persist in order to successfully regenerate lost cells, tissues or organs and rebuild all connections and functions. In this book, we will cover a few aspects of regenerative medicine highlighting major advances and remaining challenges in cellular therapy and tissue/organ engineering.

\title{
How to reference
}

In order to correctly reference this scholarly work, feel free to copy and paste the following:

Aneta Glejzer, Virginie Neirinckx, Bernard Rogister and Sabine Wislet-Gendebien (2011). Neural Crest Stem Cells from Adult Bone Marrow: A New Source for Cell Replacement Therapy?, Advances in Regenerative Medicine, Dr Sabine Wislet-Gendebien (Ed.), ISBN: 978-953-307-732-1, InTech, Available from:

http://www.intechopen.com/books/advances-in-regenerative-medicine/neural-crest-stem-cells-from-adultbone-marrow-a-new-source-for-cell-replacement-therapy-

\section{INTECH}

open science | open minds

\section{InTech Europe}

University Campus STeP Ri

Slavka Krautzeka 83/A

51000 Rijeka, Croatia

Phone: +385 (51) 770447

Fax: +385 (51) 686166

www.intechopen.com

\section{InTech China}

Unit 405, Office Block, Hotel Equatorial Shanghai

No.65, Yan An Road (West), Shanghai, 200040, China

中国上海市延安西路65号上海国际贵都大饭店办公楼 405 单元

Phone: +86-21-62489820

Fax: +86-21-62489821 
(C) 2011 The Author(s). Licensee IntechOpen. This is an open access article distributed under the terms of the Creative Commons Attribution 3.0 License, which permits unrestricted use, distribution, and reproduction in any medium, provided the original work is properly cited. 